\title{
INDIAN AND LADINO BILINGUALISM: SOCIOCULTURAL CONTRASTS IN CHIAPAS, MEXICO
}

\author{
Norman E. MaQuown \\ University of Chicago
}

The data on which the present paper is based were gathered by the field-workers, both linguits and social anthropologist, of the University of Chicago's projects among the Tzeltal and Tzotzil-speaking Indians of Chiapas, Mexico and among the Spanish-speakin non-Indians (Ladinos) of the same area (see Figure 1). There are considerable numbers of bilinguals in both groups, although the incidence of bilingualism varies greatly from place to place within the area. In the southern and southwerstern portions of the territory, where theer are large numbers of Ladinos, there are many Indian bilinguals and practically no Ladinos who know anything of the indigenous language. In the northern and, in particular, in the northeastern parts of the area, these proportions are reversed. There are very few Ladinos, and these are, for the most part, bilingual. The agents of acculturation in the north, are, in great part, the Ladinos who speak the Indian language. In the south, on the other hand, such agents are to be found among the Indians themeselves.

What such general statements fall to specify, however, is why some Ladinos in the north and some Indians in the south are very poor, some very good, agents of culture change, and what are the specific indices, both linguistic and sociocultural of such differences in individual personality, differences which account for the selection process whereby some are chosen to lead and some are not. It is the purpose of this paper, in the concrete linguistic, sociocultural and personality data available on five individuals, distributed over this continuum, to attempt to discover such specific indices, and, having discovered them, to try to rationalize the particular roles which individuals so distinguished play in the life of their changing communities. I am especially grateful to the social anthropologists Charles E. Mann of 
Stanford University, María Esther Ålvarez de Hermitte of the University of Chicago, and Marcelo Díaz de Salas of the Mexican National School of Anthopology, and to the linguists Gerald E. Williams of Stanford University, and R. Radhakrishnan, and Harvey B. Sarles of the University of Chicago for having made available to me the sociocultural, linguistic, and projective test materials on which this study depends. I have made use of taped 200 -word vocabularies, both for Spanish and for Tzeltal-Tzotzil, and of the responses (in Spanish) to two types of cultural projection tests (the conventional T. A. T.'s, and a photo-test for cultural perception devised especially for the Chicago Chiapas projects by Murial Eva Vervitsky de Hunt of the University of Chicago). In addition, I have had available to me a variety of socio-cultural census data on the five individual in question (one Ladino, and four Indians), all of whom are bilingual in varying degrecs which will be here carefully specified.

Since the features which I have here isolated as indices of bilingual adaptation are in considerable number phonological, I present first, in brief outine, the phonological systems (Figures 2-11) of the dialects involved, followed by the lists of features, so that the factual selection among the features found in these system in the usage of each of the individuals under study as well as the rationale of such selection may be made clear.

\section{Figure 2}

OCOSINGO TZELTAL
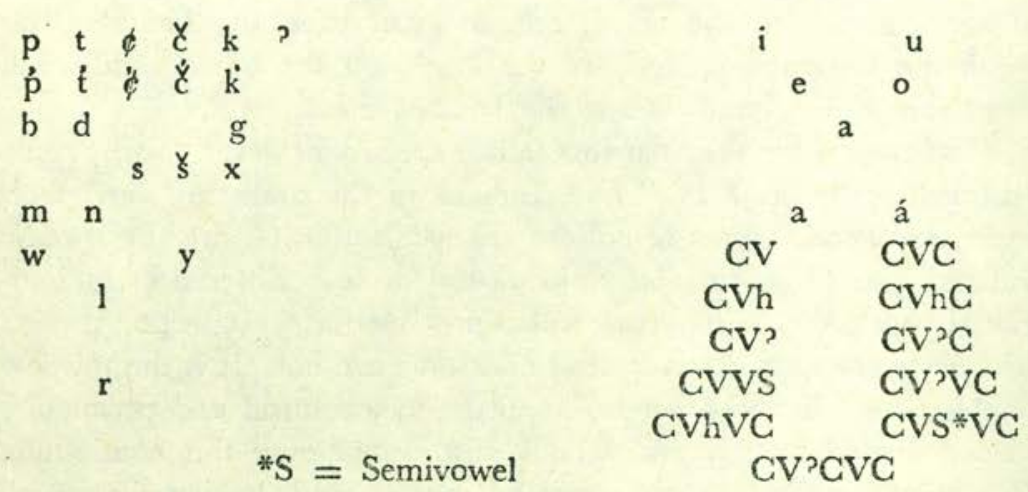

The Ocosingo Tzeltal (Figure 2) of Informant No. 1 (Ladino) contains, among others, the following phonological peculiarities which stamp it as non-Indian: 
(1) absence of glottalization (in all positions);

(2) abscence of glottal stop (in CV?CVC);

(3) abscence of stop articulation (in / $/ \mathrm{b}^{\prime} /$ ) ;

(4) assimilation of e.g. [₹] to [z] before voiced item;

(5) replacement of [V'P'] by [Vb]; of ['bp] by [vf].

The following represent instances of hyper-Indianism:

(1) [.'xak . ka.] instead of normal [.xa?.?a. ' 'agua';

(2) [.t<en.'tsum.] instead of normal [.ten.'tsun.] 'chivo';

(3) [.tu'min,] instead of normal [.tu.'min.] 'algodón';

(4) [.ta'kin.] instead of normal [.ta.'k<in.] 'seco';

On occasion, however, other, genuinely Indian, features do appear:

(1) utterance-final glottal stops (regularly);

(2) glottalization (properly placed) (sporadically);

(3) [ $\left.{ }^{\mathrm{p}} \mathrm{p}\right]$ where it should occur;

(4) $\mathrm{CVxC}$ (regularly) but with strongly fricative. [xt: in this position.

One or more of these genuinely Indian features occurred not as reactions to the linguist's elicitation formulae, but rather as echo reactions to Indian responses to the formulae. In such cases the chain Spanish-speaking elicitation Tzeltal response in Spanish context was broken, and a genuinely Tzeltal reaction was in order.

Figure 3

OCOSINGO SPANISH
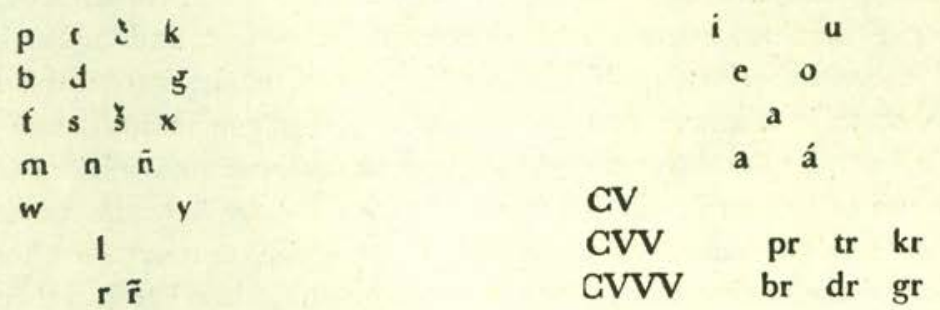

The Ocosingo (?) Spanish (Figure 3) of Informant No. 1 (Ladino), as evidenced by the text of the informant's reactions to the individual photographs in the $\mathrm{P}$ [hototest for] C[ultural] P[erception], 
departs very little from the Central Mexican phonological norm, although there are numbers of grammatical and lexical provincialisms and an occasional vulgarism. Among provincialisms, we note:

(1) ad-verbial muy (no muy se distingue);

(2) ir $a$ without $a$ (se va casar);

(3) feminine en -anta (ó alguna acompañanta ó alguna visitanta).

As a vulgarism we observe the pronunciation [.tsek.'tal.] in place of the usual [.itsel.'tal] in de raza tzectal.

Inspection of the content of Informant No. 1's Spanish-language PCP reactions produces clear evidence of his Ladino identifications:

(1) his use of the term indito for the human figures in the photos;

(2) his use of the term choza for their houses;

(3) his use of the term indumentaria for their clothing.

On the other hand, his constant use of the diminutive in _ito or _ita evidences his kindly tolerance and good will (dos inditos, su chocita, este chamaquito, está contentito, se conoce muy apuradito, chamulitas, son inditas) toward Indians, as does his use of señora of an Indian woman. Other words and phrases for identifying Indians are typically Ladino in their avoidance of more direct labels (indígenas, de raza tzectal, de raza indígena, un chamaquito ... así de la región, es del carácter de ellos). His almost exclusive reliance on clothes as providing the distinguishing line between Indian and Ladino is again typical, although it gets him into trouble when he tries to reconocile Ladino trousers and shirt with bare feet and a kerchief tied around the head. Shift of clothing from the Indian to the Ladino norm is characterized as progressive (más adelantados, una familia bastante decente y arreglada, pero ya indígenas más civilizados). The use of pewter bowls is a mark of progress (por lo tanto, ya están bastante adelantados). The refusal to recognize, among the photos, either of the curing ceremonies as such, on the other hand, indicates Indian-Ladino common sentiment on witchcraft and curing. Full identification with the non-Indian (ahorita sí se ve que está muy contento), however, is manifest in Informant No. l's reaction to the last of the twenty PCP photos. 
Figure 4

PINOLA TZELTAL
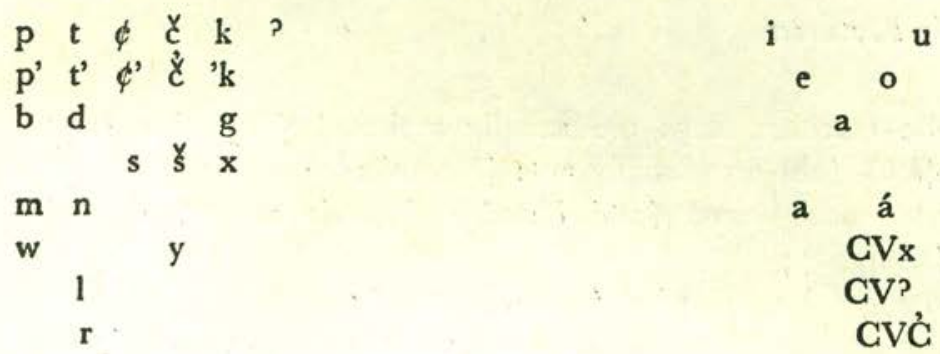

The Pinola Tzeltal (Figure 4) of Informant No. 2 (Indian) contains the following special characteristics which mark it as innovating and hispanicizing:

(1) complete lack of noun-classifiying numeral prefixes (with only one exception, the personal $t u l$, in only one instance);

(2) almost exclusive use of [b] allophone of $/ \mathrm{B} /$ (only one instance of $/ \mathrm{Pb} /$ in utterance final);

(3) use of $-/ \mathrm{VI} /$ final (adjectival) instead of nominal root initial members of the Tzeltal equivalents of Spanish adjectivenoun phrases ( $a$ hal lum, tohol beh, sikil 'ak'abal, ya 'il nah).

Other features may be interpreted as indicating a tendency toward slavish literal translation (yakat yuč il ha?: estás bebiendo agua, ha ' $i$ ' $e$ sti'awan: los perros muerden); the grasp of the second languaje is, however, not always adequate (tokal lom Pip: not cayó una lluvia fuerte but hay una neblina fuerte).

\section{Figure 5}

\section{PINOLA SPANISH (INDIAN)}
p t tै $k$
b d $g$
$f s \quad s \quad x$
$\mathrm{m}$ n $\tilde{\mathbf{n}}$
$\begin{array}{lll}w^{*} & & y \\ & & \\ & & \end{array}$

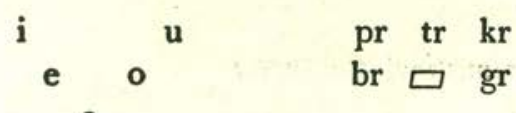
a
a á
Cía $\quad$ CVx
Cío $\mathrm{CVVx}$ 
The Pinola Indian Spanish (Figure 5) of Informant No. 2, notwithstanding his tendency toward innovation in Tzeltal, departs quite widely from the Central Mexican norms for Spanish:

\section{Phonetic Features:}

(1) the voiceless stops are usually aspirated ([k']amino largo, $a\left[k^{k}\right] i$ ) (but occasionally not: $\left.[k] a c h o\right)$;

(3) post-nasal voiced (está Usted cor[d]ando zacate) or lenis $($ tem $[\mathrm{p}] l o)$;

(3) the $/ \hat{\mathrm{r}} / \mathrm{i}$ is fricative (cerro, barriga);

(6) the final vowels are followed by voiceless echo vowels (grande [e] zope [ẹl]);

(8) utterance finâl $/ \mathrm{a} /$ is occasionally centralized ( $\mathrm{mi}$ mano derecha[a^]).

\section{Morphophonemic Features:}

(15) nasals usually fail to be homorganic with following stops or fricatives $(u[\mathrm{n}]$ perro, $u[\mathrm{n}]$ piojo) but occasionally do as-

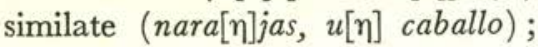

(19) cluster /gr/ replacing /dr/ (una piegra, un cegro);

(20) cluster /xu/ replacing /fu/ ([x]uego instead of fuego);

(21) cluster /ie/ replacing/ue/ (carne del pierco);

(22) ia or ío vowel clusters instead of illa or illo;

(mi rodía, amario, martio, un amario, gargantía)

(for rodilla, amarillo, martillo, armadillo, and gargatilla respectively);

(24) loss of [d] ( $i$ 'onde 'stabas? se 'espiertan);

(25) loss of initial vowel ('stá seco, 'l ombligo);

(26) loss of final vowel (lech' de vaca);

(27) loss of final syllable (mi mano zur' instead of mi mans zurda).

\section{Grammatical Features:}

(35) plural endings are omitted (somo' chiquito', dos pájaro', 'stán bueno', dos mes', cuatrocientos'), as are other final s'es ('stá lejo');

(36) plural number in possesive adjectives refers to plurality of 
possessor rather of thing possessed (sus ojo' Ustedes, sus hombros');

(38) possessive phrases lack both the article preceding the thing possessed and the preposition de which connects it with its possessor (polvo los camino', tronco los palo');

(39) feminine gender concordance fails (no andan los criaturas, un hoja verde, manta blanco, está enfermo su mujer);

(40) special forms of the second person singular of verbs (those compatible with the pronoun vos) frequently occur (vos sos, no sabés, dormite) but not to the exclusion of the usual Central Mexican forms compatible with the pronoun tú ( $¿ q u e ́$ quieres?).

\section{Lexical Features:}

(60) special lexical itms (calca del palo, mi pescuezo, un lucero, cayó una helada doble, mi carne, un zope, tzílica, murciégalo) (for corteza, cuello, estrella, fuerte or espesa, cuerpo, zopilote, and chilacayote, respectively).

Nine items $(5,19,20,22,24,25,26,40$, and 60$)$ are characteristic of local Indian Spanish, five items represent special solutions to difficult problems of shift from Indian speech habits to Spanish speech habits, and six items $(1,3,6,8,15$, and 35$)$ are clearly transfers of Indian linguistic habits into Spanish speech.

Inspection of the content of Informant No. 2's Spanish language T.A.T. reactions produces clear evidence of his distance from the Ladino world:

(1) he fails totally to recognize the violin and the sheet music in Picture No. 1 and concentrates instead on the alleged sadness and sleepiness of the figure;

(2) he fails to recognize the books carried by one of the two women in Picture No. 2;

(3) the female figure in Picture No. 3BM is identified as a man (perhaps because of the short hair-cut), and its emotional state is identified as drunkenness;

(4) grief in Picture No. 3GF is not recognized as such, but is identified as illness of physical origin;

(5) he fails to identify the resistance of the male in Picture No. 4 to female advances;

(6) and the woman in Picture No. 5 is merely identified as such and her expectant attitude is not clearly specified. 
In short, in language which continue to represent consistently Informant No. 2's special brand of Indian Spanish, this informan regularly misses standarized cues to Ladinos mores and morals.

Figures 6

PINOLA TZELTAL

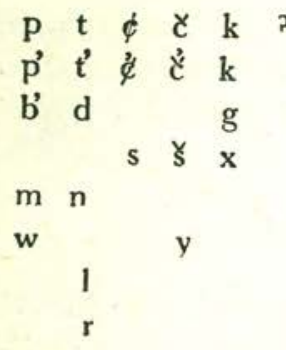

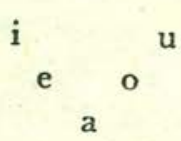

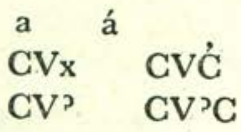

The Pinola Tzeltal (Figure 6) of Informant No. 3 (Indian) contains a number of features which clearly mark this informant as fairly conservative:

(1) the use of nominal classifiers in place of (tulát 'sos cristiano') or prefixed to numerals (túl 'ánø 'una mujer', kóht ' $\varphi$ i' 'un perro', péh té? 'un palo', hp̉ís tón 'una piedra');

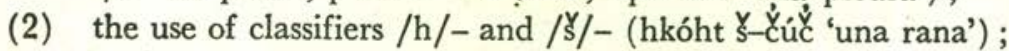

(3) clear glottal $(/ \mathrm{Pb} /$ and glottalization $(/ \mathrm{B} /)$ in the reflexes of /b'/ (ho 'é['b] Káy 'cinco pescados', ‘é'b mút 'dos pájaros', hk'a 'btík 'nuestras manos', hún ha 'bíl 'un año', '̌ín [b]éh 'caminito', ya §-báh ta milél 'lo van a matar', htá '[b.pa.] 'veinte');

(4) Tzeltal stress in Spanish loans (krisyanóh 'gente', manł̧anáh 'manzana', hkóht '̌iwóh 'un chivo', merkadóh 'mercado', pwersáh 'fuerza') (except for: 7alagúnaéh 'la laguna', Y̌léče wakáh 'la leche de la vaca' túnah — tunáh 'nopal', segúro 'seguro').

There is, on the other hand, a small number of features which mark No. 3 as inovating or hispanicizing:

(1) occasional strainght numerals (without the nominal classifier prefixes) in situations which normally require such classifiers (ho PéPb cáy 'cinco pescados', čépb mút 'dos pájaros', 'ǒsé?b tomút 'tres huevos'); 
(2) homorganic nasal (in position where the local Tzeltal does not normally have it) (غ́ílm]béh 'caminito').

\section{Figure 7 \\ PINOLA SPANISH (INDIAN)}

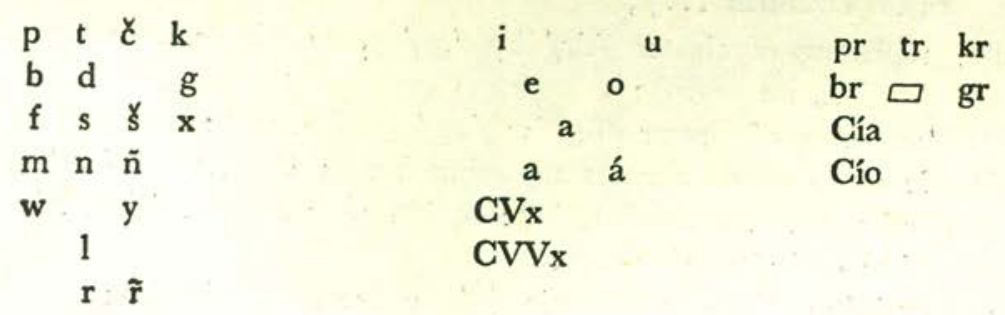

The Pinola Indian Spanish (Figure 7), of Informant No. 3, is, on the whole, even more conservative than that of Informant No. 2, and is characterized by the following special features:

\section{Phonetic Features:}

(1) the voicelss stops are occasionally aspirated (un [k']aminito,

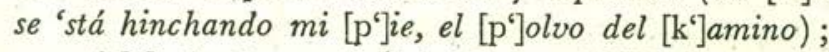

(2) use of [v] allophone of /b/ (es muy [v]i[v]o);

(4) failure of $/ \mathrm{s} /$ to assimilate to voiced allophone before voiced consonant (e[s] muy vivo);

(5) fricative / $\tilde{\mathrm{r}} /$ (una rana);

(6) the final vowels are occasionally followed by voiceless echo

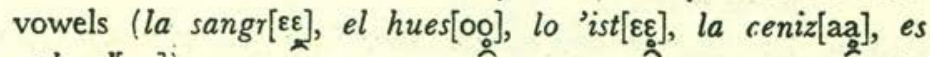
redond $[\mathrm{oog}]$ );

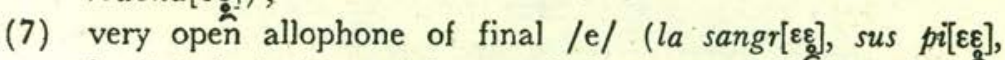

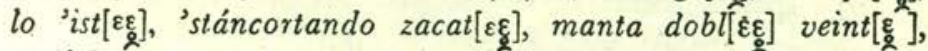

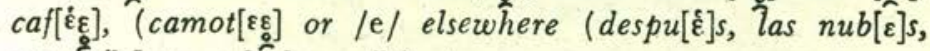

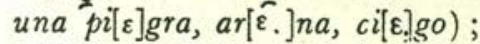

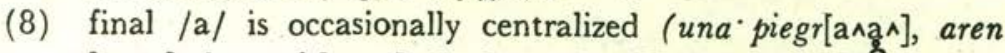

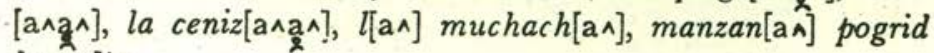
[a^å

(9) introduction of a voiceless vocoid initial in a Spanish word (or perhaps final in a preceding item) (la [i]jiel).

Morphophonemic Features:

(15) failure to assimilate a nasal to homorganic position '(so[n] buenos); 
(16) misspeaking of a labial (los pájaros muelan instead of vuelan);

(17) introduction of a nasal into a consonant cluster ( $y$ un iglesia for y una iglesia);

(18) cluster $/ \mathrm{ky} / \mathrm{replacing} / \mathrm{kr} /$ (las [ki]aturas no andan instead of las criaturas ...);

(19) replacing of cluster /dr/ by /gr/ (una piegra, manzana pogrida, un cegro);

'(20) replacing of cluster /fu/ by /xu/ (el [x] uego);

(22) ia or io vowel clusters replacing illa or illo (la semía, la rodía, amarío, martio), but: se 'stá riyendo de mí instead of se está riendo de mí);

(23) omission of preconsonantic /s/ (y 'tamos comiendo);

(24) loss of [d] ( $y$ si 'spiertan temprano $=y$ se despiertan temprano);

(26) loss of final vowel (carne de coch', por la noch').

Grammatical Features: .

(35) plural endings are omitted (somos chico', cinco pescado', dos pájaro', nuestra' oreja', sus nariz', sus pie', sus cora$\left.z o n^{\prime}\right)$ as are other final s'es (lejo[o] ') ;

(36) plural number in possessive adjetictives refers to plurality of possessor rather than of thing possessed (sus nariz', sus pie', sus barriga', sus corazon', sus higado');

(37) use of the article before the possessive adjective (está mala la su mujer);

(39) feminine gender concordance fails (el orina un inglesia, la ropa es blanco, 'stá muy frío la noch');

(40) special forms of the second person singular of verbs (vos sos ¿quién sos? ¿cómo te llamás?), although the Central Mexican forms also occur (¿qué quieres? ¿porqué no vienes? no lo sabes);

(41) misplacing of grammatical agreement in imperatives (duérmate in place of Central Mexican duérmete or Chiapanec dormite).

\section{Lexical Features:}

(60) special lexical items (una mata de palo, la cáscara del palo, carne de coch', una tijera, tzilicayote) (for árbol, corteza, puerco, tijeras, and chilacayote, respectively). 
Accuracy of Translation:

(70) occasional poor translation equivalents (sbak te hsitik $\neq$ sus ojos de Ustedes, kakantik $\neq$ la rodilla, hsitik $\neq$ tu cara).

Nine items $(5,19,20,22,23,24,26,40$, and 60$)$ are characteristic of local Indian Spanish, three items (18, 36, and 39) represent special solutions to shift difficulties between the two languages, and twelve items $(1,2,4,6,7,8,9,15,16,17,35$, and 37$)$ are clearly transfers of Indian linguitic habits into Spanish speach. Item 41 constitutes an unresolved problem (what to do with a special imperative form which reflects a status difference?). Item 70 tells us that Informant No. 3 occasionally stray from the translation stance (the three Tzeltal examples all contain the first plural possessive affixes, although none of the elicitation forms do).

Analysis of the content of Informant No. 3's Spanish-language responses to the T.A.T. pictures reveals clearly his own even greater remove from a Ladino frame-of-reference:

(1) he totally fails to see the violin, in Picture No. 1, does not note the half-closed eyes which indicate either sadness or weariness, and subsequetly identifies the young male figure as happily relaxing, and proud of his cornfield; he suggests that the figure may be that of his compadre, disregarding age, situation, and objects in the picture, treating only those things the viewer has imaginatively attributed to the figure;

(2) his only suggested reason for hypothentical sadness of one of the two female figures, in Picture No. 2, is illness;

(3) the short-haired female figure in Picture No. 3BM is identified as male, and the attitude as due to a crippling infirmity;

(4) the female figure in Picture 3GS is said to be weeping from sadnes at having lost some possesion;

(5) he totallly misses male resistance to female advances in Picture No. 4 and characterizes them both as happy;

(6) reaction to the female figure in Picture No. 5 is solely to her physical attitude--her envoroment, characteristically Ladino, is totally ignored;

(7) the female figure in Picture $6 \mathrm{BM}$ is identified as male, the house interior is identified as a park, and the thoughtful attitude of the young man is characterized as conceit;

(8) in Picture 6GF, the short-haired lip-sticked female figure is identified as a boy, and the pipe-smoking middleaged figure behind 
her is describe as a little old man smoking: a cigar, and the livingroom in which they are talking is said to be a summer-house in a garden;

- (9) the doll in the hands of the pre-adolescent girl in Picture No. 7GF is said to be a baby, and the girl's mother (the baby's grandmother) is advising her to feed it, since it is crying;

(10) the scense with the men (one of whom is holding a knife) hovering over a prone figure, in Picture No. 8BM, with a thoughtful young man in the foreground, is interpreted as a post-violence scene in which the prone figure is the body of a man who has been murdered, and the formal clothes of the young man are said to be mourning-dress.

All of these reactions are typically non-Ladino, and the Ladino attributes of attitudes and enviroments are nowhere perceived.

\section{Figure 8}

PINOLA TZELTAL
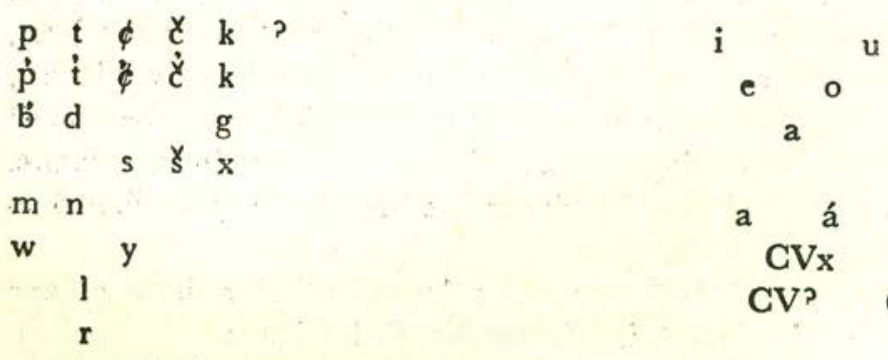

The Pinola Tzeltal (Figure 8) of Informant No. 4 (Indian) contains certain features which mark this informant as extremely conservative:

(1) the very frequent use of nominal classifiers prefixed to numerals (h-túl 'ánł 'una mujer', ho'kóht X'áy 'cinco pescados', hpéh té' 'un árbol', 'oYpis tomút 'tres huevos', hpih tón 'una piedra', hì̇is 'asarón 'un azadón');

(2) clear glottal $/ \mathrm{Pb} /$ and glottalization $/ \mathrm{b} /$ in the reflexes of /b'/ (k'eYam k'a'bal 'mano izquierda', yak ta s-b'ohel 'ak 'está cortando zacate'):

(3) the Spanish loans which appear are almost all completely assimilated (mantáh 'tela', maņanáh 'manzana', Jasarón 
'azadón', těelešetík 'tijeras', kapéh 'café', tunáh 'nopal', nalašetik 'naranjas', tulesnáh 'durazno').

On the other hand, there are also several features of his Tzeltal which mark him as innovating (under Spanish influence):

(1) use of some unassimilated loans (kristyánoh 'gente', spulmoník 'sus pulmones');

(2) use of plurals of items in circumstances in which plurals would not, in Tzeltal, normally be used ( $y a$ s-ti' awan ' $f i$ ' etik "muerden los perros", tokaletik 'las nubes', tanetik ka'al 'ceniza', teYeleYetik 'tijeras', nalaY̌tick 'naranjas')

Figure 9

PINOLA SPANISH (LADINO)

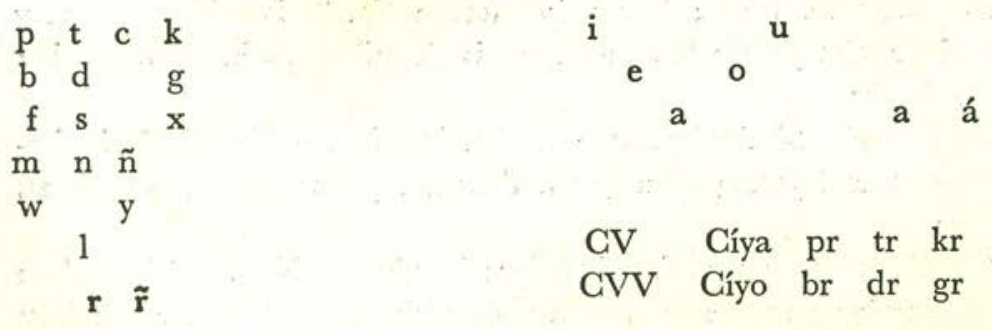

The Spanish (Figure 9) of Informant No. 4, however, shows hardly any influence whatsoever, either of Pinola Tzeltal or Pinola Indian Spanish:

(4) failure to assimilate /s/ to a following voiced consonant (tre[s] huevos);

(19) replacement of /dr/ by /gr/ (una piegra);

(28) insertion of $/ y /$ in intervocalic hiatus (se está riyendo de mí: normal riendo);

(35) omission of final /s/ (cuatrociento').

On the contrary, many of the features characteristic of local (Indian) Spanish are not found in this informant's speech:

(5) his / $\tilde{r} /$ is a clear trill;

(20) his fuego is pronounced with an /f/;

(22) his illa and illo pronounce their $l l$;

(24) his [d] is not lost. 
This informant presents very precise translation equivalents in what is otherwise very good Central Mexican Spanish. (kehtikik 'nuestros dientes', tukel layalbon 'él me dijo', $h a$ ' '⿳̛̀c iłeh 'la muchacha', yakon ta ' $a$ 'tel ta hk'al 'estoy trabajando en mi milpa').

Informant No. 4 contrasts with Informant No. 2 and No. 3 not only negatively, in the precision of his translation, where they are imprecise, but also positively in having as prevalent allophones of /w/ [gu] and [gu], characteristic of neither of his two languages alone, but found in both.

Analysis of the content of Informant No. 4's responses to the T.A.T. pictures shows a considerable sophistication in things Ladino and an accentuation of Ladino ideals of conduct:

(1) the thoughtful boy, in Picture No. 1, is described as an orphan, having his music, as studious and hard-working, in preparation for becoming a great man;

(2) the man with a horse, in Picture No. 2, is said to be very industrious, the young female figure is described as being a teacher with a book;

(3) the short-haired female figure, in Picture No. 3BM, is described as a sad young man (or a drunken young man), who is an orphan;

(4) the woman covering her face in picture No. 3GF is said to be weeping because she cannot earn enough money to make a living;

(5) the scence of the reluctant male, in Picture No. 4, is described as a scene of marital bliss in which a loving husband and wife, faithful to each other, are in constant fear, lest one or the other die;

(6) in Picture No. 5, all the emphasis is on the material possessions in the house of the woman of affluence, who is good, and intelligent, too;

(7) in Picture No. 6BM, both female and male figures are correctly identified as to sex; the former is given the rôle of mother, the latter that of a studious, intelligent son who cares for her needs;

(8) the female figure in Picture No. 6GF is identified as male, and in him our informant sees a studious son and a loving father, and expatiates on the advantages of having a father to care for one;

(9) in Picture No. 7GF, the mother and daughter are identified as such, but the doll is described as the daughter's baby, and much is made of the possibility that the baby might die;

(10) the knife scene, in Picture No. 8BM, is described as involving doctors hired by a dutiful and loving son to operate on a loving father suffering from a serious illness; 
(11) the smiling young lady of Picture No. 8GF is said to be sad because she is an orphan;

(12) the resting workers, in Picture 9BM, are made the motive of a discourse on the salutary effects of rest for the tired body;

(13) the two women of Picture No. 9GS are said to love each other like sisters;

(14) in Picture No. 10, marital bliss is again extolled;

(15) in Picture No. 11, the informant sees and elephant, of whom people are wrongly afraid, and some vultures which are held in check by a man;

(16) in Picture No. 12M, God has sent a priest to bless a dying person, whom He will take, if that is His will;

(17) in Picture No. 12F, an old woman is seen side by side with her son (here a femals figure is misidentified as a male), and the virtues of filial piety are extolled;

(18) in Picture No. 12BG, a pool for bathing in a summer scene is identified;

(19) in Picture No. 13MF, a man is said to be mourning his deceased wife;

(20) in Picture No. 13B, the child is said to be eating fruit without a care in the world, and the advantages of having parents who care for one is indicated;

(21) in Picture No. 13G, a child is climbing stairs;

(22) in Picture No. 14, a carpenter is working in darkness;

(23) in Picture No. 15, a man is described as standing among crosses and squares;

(24) the blank Picture No. 16 motivates a long discourse on the baptism of a child;

(25) the rope-climbing naked figure, in Picture No. $17 \mathrm{BF}$, is motive for a discourse on the use of ropes to climb trees with low branches;

(26) the Picture No. 17GF (of the sun shining on the bridge and the boat-docks) gives rise to a discussion of the shape of the world and of night and day;

(27) the man heid by hands, in Picture No. 18BM, is said to represent an ill person supported by friends;

(29) the cabin-in-the-snow scene, in Picture No. 19, is said to represent a tractor;

(30) the hatted figure beneath a street-lamp, in Picture No. 20, is said to represent a man who went out to buy medicine at a late hour. 
This informant sees Ladino goals in almost all subjects. His preoccupation with orphanhood, and with death through illness, however, as well as his failure to recognize dolls and short-haired females mark him quite clearly as an Indian in his perception of the Ladino world.

Figure 10

SAN BARTOLO TZOTZIL

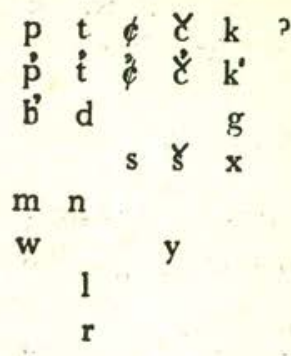

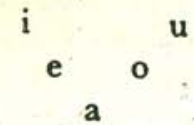

a á

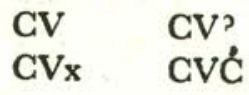

The Tzotzil (Figure 10) of Informant No. 5 likewise presents features which mark him as carefully conservative:

(1) use of nominal classifiers prefixed to numerals (hwo 'ánł 'una mujer', hkot'̧' $i$ ' 'un perro');

(2) use of 'xul 'holy, sacred' with the names of numerous objects belonging to the category of revered natural phenomena (trees, seed, sun, moon, star, rain, stone, clouds, fire, night, sky, day, fog, year, cornfield, drum, God);

(3) use of 'in 'small' as a similarly reverential diminutive for other objects (feather, bird, frog, butterfly).

His translation equivalents for the Spanish elicitation formulae are exact ('asátik ho'ơ̌úk 'sus ojos de Ustedes', sb'ákel ketík 'nuestros dientes', hkót $i k^{\prime}{ }^{\prime}{ }^{\prime} l$ ' 'a' 'un perro negro', '̇ul Xáwokil tók 'la neblina (santa nube del rayo)').

\section{Figure 11 \\ SAN BARTOLO SPANISH (INDIAN)}

$\begin{array}{cccc}\mathrm{p} & \mathrm{t} & \succ & \mathrm{k} \\ \mathrm{b} & \mathrm{d} & & \mathrm{g} \\ \mathrm{f} & \mathrm{s} & \boldsymbol{\zeta} & \mathrm{x} \\ \mathrm{m} & \mathrm{n} & \tilde{\mathbf{n}} & \\ \mathrm{w} & & \mathrm{y} & \\ & 1 & & \\ & \mathbf{r} & \tilde{\mathbf{r}} & \end{array}$

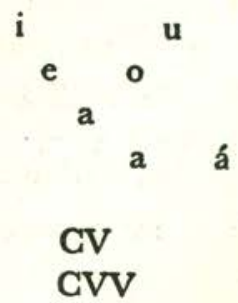


The Spanish of Informant No. 5 is in general near the Central Mexican norm, but departs from it some respects:

(5) his $/ \mathrm{r} /$ is fricative (reboso, corral);

(19) replacement of cluster /dr/ by /gr/ (en una piegra);

(42) omission of $a$ in the expression ir a (hacer algo) (lo va calentar);

(43) use of general form lo not in agreement as to number or gender with those of the objects to which it refers (él lo estí cuidando las cositas que tiene, lo va calentar una taza de agua);

(60) lexical peculiarities (está poco triste, pos, ansí, apuntando en el dedo, saber de dónde for algo, pues, así, con, quién sabe);

(61) gender shift (el costumbre, but also la costumbre). Noteworthy is the careful use of tampoco which not even all native speakers of Spanish use in its required context.

Indian Informant No. 5's perceptions of the Indian world, found in the photographs of the P.C.P., differ considerably from those of Ladino Informant No. 1:

(1) in P.C.P. No. 1, Informant No. 5 sees the girl as being from cold country (by contrast with San Bartolo);

(2) in P.C.P. No. 2, he sees the couple as Chamulas from Amatenango (which is Tzeltal, not Tzotzil);

(3) in P.C.P. No. 3, he sees the old man as sad and everyone as solemn as if in church (it is a weding);

(4) In P.C.P. No. 4, he sees the old man as from Aguacatenango (he is in fact from Pinola), and as guarding his possessions;

(5) in P.C.P. No. 5, he sees the ladies as supping, as in a house, as Ladinos from Pinola (they are pinola Indians in a grave-yard on All Souls' Day);

(6) in P.C.P. No. 6, he sees a Ladino lady as about to heat a cup of water (she is an Indian from Pinola);

(7) in P.C.P. No. 7, he sees an Indian boy with a sling-shot as Ladino (because he has good trousers);

(8) in P.C.P. No. 8, he sees a Ladino house in San Cristóbal (it is in fact to be found in Pinola);

(9) in P.C.P. No. 9, he sees a man blowing the fire with his head tied up like a chef's (it is, in fact, a curing ceremony); 
(10) in P.C.P. No. 10, he sees old men (Chamulitas) playing the fife and drum (they are in fact Pinola Tzeltal, not Chamula which is Tzotzil);

(11) in P.C.P. No. 11, he sees a lady from Ladino Soyatitán as a Chamula redressed as a Ladino.

Our San Bartolo Informant No. 5 sees a clear line between San Bartoleños and others, some from cold country. The line between redressed Indian and Ladinos, however, is not so clear to him, nor is the line between one cold-country Indian and another. For the rest, his description of the content of the P.C.P. photographs is relatively colorless. He, like the Ladino from Ocosingo, fails to identify curing ceremonies as such. He himself, as revealed by his reactions to the P.C.P., is a relatively dispassionate person, who reacts without great involvement to external stimuli.

In the Spanish, as we have seen in these test responses, of Informants 2, 3, 4, and 5, all Indians, only one feature (19) is shared by all four, and only two features ( 5 and 35 ) are shared by three (by 2, 3, and 5 , and by 2, 3, and 4, respectively), but eleven are shared by Informants 2 and 3, and two by Informants 3 and $4(1,6,8,15,20,22,24,26,36,39,40$, and 4 and 28, respectively). Of the 11 shared by Informants 2 and 3, features 1,6 , $8,15,22,26,36$, and 39 are Indianizing features, features 20, 24, and 40 are local or sub-standard Spanish, and the combination characterizes a special Indian Spanish dialect. Features 3, 21, 25, 27, 38 , and 60 are limites to Informant 2, features 2, 7, 9, 16, 17, 18, 23, 37,41 , and 60 are limited to Informant 3, whereby it is apparent that no two individuals, even those speaking what is essentially the same dialect, make exactly the same selection of Indianizing (or, for that matter, Hispanicizing) features.

Informant No. 1, who speaks good Central Mexican Spanish with only a slight local rural tinge, speaks fluent but inarcurate local Tzeltal, and identifies himself, by his reactions to the P.C.P. as a benevolent but undoubted Ladino. His job is that of local Commissioner of Indian Affairs.

Informant No. 2, who speaks Pinola Indian Spanish with wide departures from the Central Mexican norm, nonetheless speaks a Pinola Tzeltal which is innovating and in some respects, hispanicizing. His transfer from one to the other is, however, difficult, and his translations lack precision. His reactions to the T.A.T. show clear evidence of his considerable distance from the Ladino world, and his 
attempts at fluent Spanish never progress beyond the Indian Spanish level. $\mathrm{He}$ is caught between his desire for Ladinization and his inability to attain it. $\mathrm{He}$ is a local curer.

Informant No. 3, who speaks a conservative Pinola Indian Tzeltal, on rare occasions innovates or hispanicizes. He speaks an Indian Spanish which departs even farther from the Central Mexican norm than that of Informant No. 2, and contains further special features not found in the speech of No. 2. His reactions to the T.A.T. are far removed from the Ladino frame-of-reference, and he repeatedly misses in the pictures Ladino attitudes and environments. He is a local farmer.

Informant No. 4, who speaks an extremely conservative Pinola Indian Tzeltal, has, nonetheless, certain minor features which mark him as innovating (under Spanish influence). His Spanish, on the other hand, is closer to the Central Mexican norm than that of either of his two fellow Pinoltecos. Indeed, it betrays only very occasional traces of departures from this norm, not even in the direction of local Ladino Spanish. He transfers quickly from one language to the other, and his translation equivalents are extremely precise. $\mathrm{He}$ has, both in his Tzeltal and in his Spanish speech, a single feature, the fricative / w/ which sets him apart from his fellows. His responses to the T.A.T. show great sophistication in things Ladino and in Ladino ideals of conduct, although his private themes of orphanhood and the fear of death through illness frequently recur, and his failure to recognize items such as dolls and short-haired women betray his Indian origin. $\mathrm{He}$ is an orphanned tubercular who is employed as a town-clerk and interpreter and functions as a kind of communications officer between Indians and Ladinos.

Informant No. 5, finally, is in his Tzotzil speech conservative, in his local San Bartolo Spanish fluent, and in his translation equivalents exact. His perceptions of his fellow Indians in the P.C.P. differ considerably, as one might expect, from those of Ladino Informant No. 1. He is, nonetheless, imprecise in his identification of Indians elsewhere, and, in some cases confuses them, since dress seems to be his primary index, with Ladinos. His responses to the P.C.P. do not strongly identifiy him with the Indians from elsewhere when he sees them, and he reacts somewhat dispassionately to other stimuli in their environment. He is employed as informant to the anthropologist who is working San Bartolo.

Informant No. 1 is the only Ladino among our bilinguals and plays his role well. 
Informants No. 2 and No. 3 both innovates and hispanicize, the former frequently, the latter rarely, in their Tzeltal. Both speak fluent Indian Spanish, but the speech of both of them departs widely from the Central Mexican norms. Although No. 2 still strives to approach that norm, No. 3 is blissfully unaware of its existence. Bilingualism with No. 2 is a means for change, but he finds himself completely at home in neither sociocultural community. For No. 3, bilingualism seems to have no important function at all-it would be hard to be more monocultural and yet bilingual.

Informants No. 4 and 5, on the other hand, both speak an Indian language which is even more conservative than that of Informant No. 3. At the same time, their Spanish departs only slightly from the Central Mexican norm. No. 4, in his reactions to the T.A.T., shows himself to be a good interpreter of Ladino culture, although not fully identified with it. No. 5 , however, although like No. 4 is most other respects, is dispassionate toward it, and is quite happy to keep his distance.

Only Informants 1 and 4, therefore, succeed as mediators between the two cultures, the first by virtue of his attitude more than through his performance, the latter by skliful manipulation of the communication media of two worlds. 